

\section{TABLE OF CONTENTS}

\section{ArTiCLES}

When are two algorithms the same?, by ANDreas Blass, NaCHum DerShowitz,

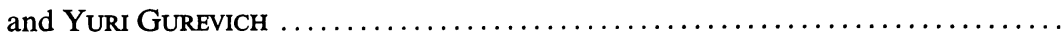

Borel reducibility and classification of von Neumann algebras, by ROMÁN SASYK

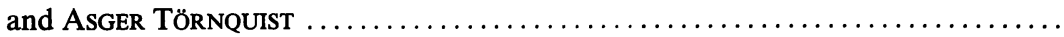

Automatic continuity of group homomorphisms, by CHRISTIAN ROSENDAL .........

REVIEWS

R. Gibson (editor), Quintessence: Basic readings from the philosophy of W. V. Quine.

Reviewed by Alex Orenstein ..................................... 215

R. Kaye, The mathematics of logic. Reviewed by Rafal Urbaniak............. 216

P. Smith, An introduction to Gödel's theorems. Reviewed by Arnon Avron ......... 218

James H. Schmerl's nine papers on models of PA. Reviewed by Roman Kossak...... 222

W. Kubiś et al., Four papers on inverse systems and Valdivia compacta. Reviewed by

Mirna Džamonja and Grzegorz Plebanek ............................

2008 Winter Meeting of the Association for Symbolic Logic, The Marriott Hotel,

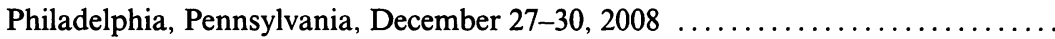

2008-2009 Winter Meeting of The Association for Symbolic Logic, Marriott

Wardman Park Hotel, Washington, DC, January 7-8, 2009 ................

10th Asian Logic Conference, Kobe, Japan, September 1-6, 2008 ...............

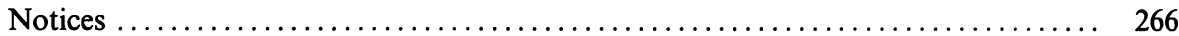

The Bulletin of Symbolic Logic (ISSN print: 1079-8986, ISSN online: 1943-5894) is published quarterly, in the months of March, June, September, and December, by the Association for Symbolic Logic, Inc., 124 Raymond Avenue, Poughkeepsie, NY 12604-0001, USA. Periodicals postage is paid at Poughkeepsie NY and at additional mailing offices. The BuLLETIN is distributed with THE JOURNAL OF SYMBOLIC LOGIC; the 2009 annual subscription price for the two journals is US\$575. Online subscription is available from Project Euclid; visit http://projecteuclid.org/bsl. Postmaster: Send address changes to The Bulletin of Symbolic Logic, c/o American Mathematical Society, 201 Charles Street, Providence, RI 02904-2294, USA. Business correspondence should be sent to the Secretary-Treasurer of the Association. Charles Steinhorn (address on inside back cover).

The Bulletin, the Journal, and the Review of Symbolic Logic are the official organs of the Association for Symbolic Logic, an international organization for furthering research in all aspects of symbolic logic. The BULLETIN encourages submission of Articles and Communications in all areas of logic, including mathematical or philosophical logic, logic in computer science or linguistics, the history or philosophy of logic, and applications of logic to other fields. The BULLETIN also publishes reviews of publications in logic.

Articles should be of broad interest and accessible to a wide audience of logicians. They may be purely expository, survey, or historical articles, or they may contain, in addition, new ideas or results or new approaches to old ones.

Communications should be announcements of important new results and ideas in any aspect of logic; they may be short papers in their final form or preliminary announcements (extended abstracts, position papers) of longer, full papers that will be published elsewhere. In any case, they should include, in addition to a description of the new results or ideas, enough history, background, and explanation to make the significance of the work apparent to a wide audience. Communications will be quickly refereed and published within six months of the submission of final versions.

$10987654321 \quad 141312111009$

Continued on inside back cover 

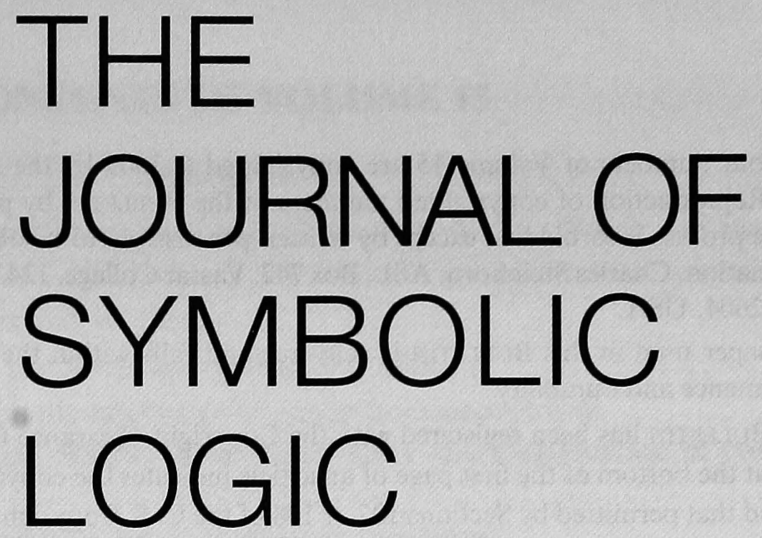

\section{Edited by}

Rod Downey, Managing Editor

John Baldwin

Michael Rathjen

Ilijas Farah

Erich Reck

Volker Halbach

Katrin Tent

Martin Otto

\section{Reviews Editors}

Steve Awodey, Managing Editor for Reviews

John Baldwin

Hannes Leitgeb

John Burgess

Roger Maddux

Mark Colyvan

André Nies

Anuj Dawar

Carsten Schürmann

Mirna Džamonja

Marcelo Fiore

Kai Wehmeier

Matthias Wille

VOLUME $15 \cdot 2009$ 
The four numbers of Volume 15 are copyrighted (C2009 by the Association for Symbolic Logic, Inc. Reproduction of copyrighted numbers of the BULLETIN by photostat, photoprint, microfilm, or like process is forbidden, except by written permission, to be obtained from the Secretary of the Association, Charles Steinhorn, ASL, Box 742, Vassar College, 124 Raymond Avenue, Poughkeepsie, NY 12604, USA.

The paper used in this BULLETIN is acid-free and falls within the guidelines established to ensure permanence and durability.

This BULLETIN has been registered with the Copyright Clearance Center, Inc. The appearance of a code at the bottom of the first page of an article indicates the copyright owner's consent for copying beyond that permitted by Sections 107 or 108 of the U. S. Copyright Law, provided that the per-copy fee stated in the code is paid directly to Copyright Clearance Center, Inc., 222 Rosewood Drive, Danvers, MA 01923, USA. This consent does not extend to copying for general distribution, for advertising or promotion purposes, for creating new collective works, or for resale. Specific written permission for such copying must be obtained from the Association. 


\title{
CONTENTS OF VOLUME 15
}

\author{
ARTICLES
}

Blass, Andreas, Dershowitz, Nachum, and Gurevich, Yuri. When are two

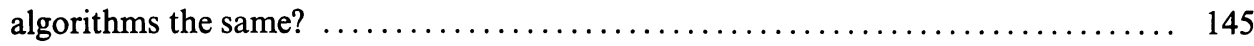

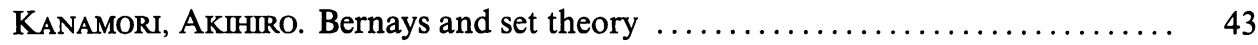

PlisKo, VALERY. A survey of propositional realizability logic $\ldots \ldots \ldots \ldots \ldots \ldots \ldots . \quad 1$

Rosendal, Christian. Automatic continuity of group homomorphisms ....... 184

SASYK, ROMÁN and TÖRNQUIST, ASGER. Borel reducibility and classification of von Neumann algebras $\ldots \ldots \ldots \ldots \ldots \ldots \ldots \ldots \ldots \ldots \ldots \ldots \ldots \ldots \ldots \ldots \ldots \ldots \ldots . \ldots \ldots$

URQuHART, AlasdaIR. Enumerating types of Boolean functions $\ldots \ldots \ldots \ldots \ldots \ldots 273$

\section{COMMUNICATIONS}

Deloro, AdrIEn. Actions of groups of finite Morley rank on small abelian groups 70 KASTERMANS, BART. Isomorphism types of maximal cofinitary groups . . . . . . 300

SIMPSON, STEPHEN G. Mass problems and measure-theoretic regularity . ....... 385

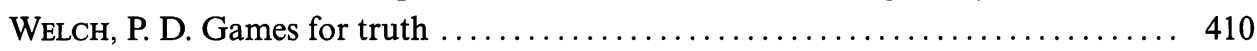

REVIEWS

M. Wille, Die Mathematik und das synthetische Apriori. Reviewed by Mark van Atten $\mathrm{R}$. Gibson (editor), Quintessence: Basic readings from the philosophy of $W$. V. Quine.

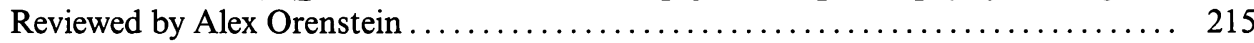

R. Kaye, The mathematics of logic. Reviewed by Rafal Urbaniak ............ 216

P. Smith, An introduction to Gödel's theorems. Reviewed by Arnon Avron ....... 218

James H. Schmerl's nine papers on models of PA. Reviewed by Roman Kossak .... 222

W. Kubiś et al., Four papers on inverse systems and Valdivia compacta. Reviewed by Mirna Džamonja and Grzegorz Plebanek ........................ 227

R. Krömer, Tool and object. Reviewed by Jean-Pierre Marquis ............. 320

On Moore's mapping reflection principle. Reviewed by Matteo Viale.......... 322

M. Friedman and R. Creath (editors), The Cambridge companion to Carnap. Reviewed by James Justus . . . . . . . . . . . . . . . . . . . . . . . . . . 428

T. Gowers (editor), The Princeton Companion to Mathematics. Reviewed by Juliette

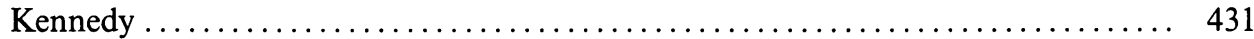

U. Blau, Die Logik der Unbestimmtheiten und Paradoxien. Reviewed by Ralf

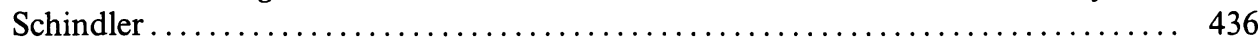

IN MEMORIAM

Leon Albert Henkin, 1921-2006. By J. Donald Monk .................. 326

In memoriam: Paul J. Cohen, 1934-2007. By ANiL Nerode ................ 439 


\section{Meetings of the Association for Symbolic Logic}

2008 European Summer Meeting of the Association for Symbolic Logic, Logic Colloquium '08, Bern, Switzerland, July 3-July 8, $2008 \ldots \ldots \ldots \ldots \ldots \ldots \ldots \ldots$ 2008 Winter Meeting of the Association for Symbolic Logic, The Marriott Hotel, Philadelphia, Pennsylvania, December 27-30, 2008

2008-2009 Winter Meeting of The Association for Symbolic Logic, Marriott Wardman Park Hotel, Washington, DC, January 7-8, 2009 229 2009 North American Annual Meeting of the Association for Symbolic Logic, University of Notre Dame, Notre Dame, Indiana, May 20-May 23, 2009

MeEtings SPONSORED by THE Association for Symbolic Logic

10th Asian Logic Conference, Kobe, Japan, September 1-6, 2008

XIV Latin American Symposium on Mathematical Logic (SLALM), Paraty, Brazil, May 11-17, 2008

15th International Symposium on Temporal Representation and Reasoning (TIME 2008), Montréal, Canada, June 16-18, 2008

Notices $140,266,379,528$

Officers and Committees of the Association for Symbolic Logic ... 465 Members of the Association 